\title{
SSynthesis
}

International Scientific Conference of IT and Business-Related Research

\section{DISTRIBUTING TOURISM AND TRAVEL SERVICES IN SERBIA - TRADITIONAL TRAVEL AGENCIES/TOUR OPERATORS VS. ONLINE DISTRIBUTION}

\author{
DISTRIBUCIJA USLUGA VEZANIH ZA TURIZAM I PUTOVANJA U SRBIJI - TRADICIONALNA (TURISTIČKE \\ AGENCIJE/ORGANIZATORI PUTOVANJA) U ODNOSU NA ELEKTRONSKU DISTRIBUCIJU USLUGA
}

\author{
Vesna Spasić, Danijel Pavlović, Nenad Stanić \\ Singidunum University, 32 Danijelova St., Belgrade, Serbia
}

\begin{abstract}
:
Online distribution of travel and tourism services has grown drastically over the last 20 years. Highly developed online tourism and travel markets, such as the USA, the UK, and Germany, have already reached the maturity stage and further dynamic growth could not be expected. At the same time, new online markets, such as Russian Federation and China, have emerged along with the expansion of the powerful new digital intermediaries. This paper evaluates online travel and tourism services distribution trends in Serbia. One of the main aims of the study is to identify the factors that motivate the prospective tourists to choose traditional travel agencies/tour operators instead of booking travel and tourism services online. The results have shown that there are discrepancies in the use of the Internet for online booking in comparison to the traditional approach to distribution of tourism and travel services. Nevertheless, the traditional form of distribution still represents the largest part of the overall distribution of tourism and travel services in Serbia.
\end{abstract}

\section{Key words:}

travel agencies, tour operators, online distribution, traditional distribution, Serbia.

\section{INTRODUCTION}

In developed travel generating countries, many tourists obtain tourism products by means of the Internet for searching and booking tourism and travel services online. In previous years, the USA travel and tourism market and most developed travel generating countries in Europe (e.g. Great Britain, Germany etc.) completely dominated in worldwide online tourism transactions. In recent years, along with the emergence of new markets (e.g. The Russian Federation and China), online distributions have increased globally and online penetration (the percentage of travel booked online) has increased faster (PhoCusWright Inc., 2011). In accordance with these global trends, evaluation of online travel and tourism services distribution trends in Serbia is essential.

Academic interests in e-tourism have grown up over the last 20 years, especially in the field of distribution process changes and disintermediation in tourism market. CTs implication on distribution in tourism industry is argued by Poon (1993). Poon also indicates changes in travel agents' business (Poon, 2001). Buhalis and Laws (2001) emphasize the process of transforming the distribution of travel products. The future of eTourism intermediaries is analysed by Buhalis and Licata (2002). Holloway (2004) indicates the use of new technologies and multiple benefits of tourism industry. Beiderman (2008) emphasizes the

\section{Apstrakt:}

Elektronska distribucija usluga vezanih za turizam i putovanja beleži ogroman rast u proteklih 20 godina. Visoko razvijena elektronska turistička tržišta, poput SAD-a, Velike Britanije i Nemačke, dostigli su fazu zrelosti, pa se na ovim tržištima ne može očekivati dalji dinamičan rast. Istovremeno se pojavljuju i nova elektronska turistička tržišta, kao što su Rusija i Kina, gde je primetan rast novih elektronskih posrednika. U ovom radu se ispituju trendovi u elektronskoj (online) distribuciji usluga vezanih za turizam i putovanja u Srbiji. Jedan od glavnih ciljeva istraživanja jeste da se utvrde razlozi zbog kojih potencijalni turisti biraju tradicionalne turističke agencije/organizatore putovanja umesto da rezervišu usluge preko Interneta. Rezultati su pokazali da postoje razlike u korišćenju Interneta za online rezervacije u odnosu na tradicionalni pristup distribuciji usluga. Tradicionalni oblici distribucije i dalje čine najveći deo sistema ukupne distribucije usluga u Srbiji vezanih za turizam i putovanja.

\section{Ključne reči:}

turističke agencije, organizatori putovanja, elektronska (online) distribucija, tradicionalna distribucija, Srbija.

role of new aggregators - Meta search engines while Beech and Chadwick (2006) present travel chain of distribution as similar to traditional industry. These authors have analysed changes that ICT and the Internet brought to consumer behaviour and highlight the implication on the tour operator and travel agencies' business. In recent years, many authors have argued future tendencies: Liach et al. argue about the current situation of disintermediation and achievement of customer's loyalty with a special emphasis on purchasing airline tickets (Liach et al., 2013), Chiappa studies the role of traditional travel agencies and measures the perception of different groups of Italian online buyers providing insight into the scientific debate on disintermediation (Chiappa, 2013). The use of the Internet for travel planning and the domination of OTA's is argued by Xiang, Magnini and Fesenmaier (2015). They also emphasize and argue that the adoption of the Internet has reached a level of saturation. Bogdanovych et al. (2006) measure tendencies in the use of travel agents instead of online booking of tourism services.

In Serbia, on the contrary, not much extensive research has been carried out on the problem although there are some studies measuring the use of information technologies in incoming travel agencies business (Spasić et al., 2014.) In this paper, we use previously tested research methodology (Bogdanovych $e t$ al., 2006) to define the trends in online distribution, on one hand, and traditional distribution of tourism and travel services in Serbia, on the other hand. 


\section{RESEARCH METHODOLOGY}

The following questions are addressed in this study: What are the preferences of young people in terms of booking tourism and travel services in Serbia? What are the trends in distribution of travel and tourism services in Serbia? Is traditional distribution still prominent in travel agencies and tour operators' business in Serbia?

We have chosen a questionnaire as a research instrument (Zikmund et al., 2010, p. 232). Respondents were surveyed at the end of December 2014 and mid-February 2015. They were familiar with research goals and their contributions. The questionnaire consisted of 20 questions, two of which are related to general characteristics of the respondents. Three questions consider the evaluation of elements related to the booking of tourist services in Serbia. Two questions were open-ended and referred to the future of traditional travel agencies and tour operators. The remaining questions were related to the use of the Internet and traditional approach to booking tourism and travel services. For the purpose of this study, a population of young people was selected, i.e., third year students of tourism and hospitality management, assuming that they are sufficiently educated about the changes in tour operators and travel agency business. They were also selected as a potential tourist demand that is more intensive in the use of the Internet compared to other age groups. A total of 50 completed questionnaires were collected.

\section{SAMPLE}

The study included a total of 50 young respondents, 38\% male and $62 \%$ female (Fig. 2). The age groups of survey participants are shown in Fig. 1.

The largest number of respondents is in the age group between 21 and 25 years old, i.e., $72 \%$ or 36 respondents. The age group between 18 to 21 years old accounts for $22 \%$ or 11 respondents, and in the age group over 25 , there are three respondents or $6 \%$.

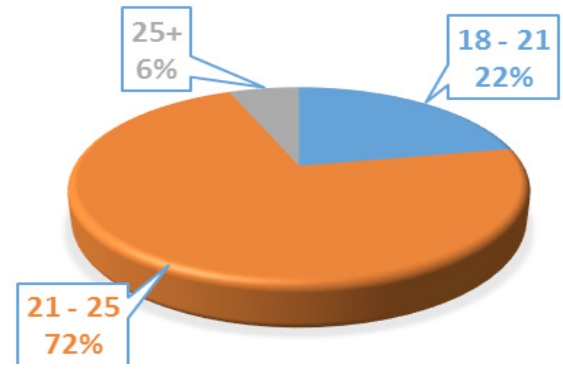

Figure 1. Age

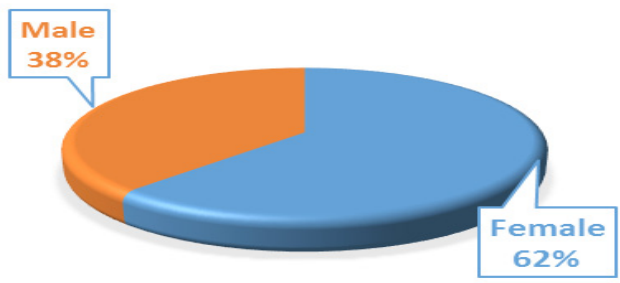

Figure 2. Gender

\section{DATA ANALYSIS}

The results of respondents' answers are presented in Table 1. Based on those results, the following will be analysed: travel behaviour, the way of searching and booking travel and tourism services and interaction, evaluation of booking over the Internet in Serbia, booking of tourism and travel services via travel agency/tour operator.

\section{TRAVEL BEHAVIOUR}

The survey results (Table 1) show that $40 \%$ of respondents travel once or twice a year, $24 \%$ travel three to four times, and the same percentage goes to those who travel five to six times a year. According to statistics, $8 \%$ of respondents travel more than six times a year and $4 \%$ do not travel at all. Most of the respondents use travel agencies/tour operator services for travelling purposes (54\%) while $44 \%$ travel individually. $44 \%$ of respondents prefer to travel by travel agencies/tour operators whose services they have used before, $28 \%$ often change travel agencies/tour operators and $22 \%$ do not use their services at all. The location of travel agencies/tour operator is relevant only to $6 \%$ of respondents.

\section{THE WAY OF SEARCHING AND BOOKING TRAVEL AND TOURISM SERVICES AND INTERACTION}

Regularly, $46 \%$ of respondents use the Internet to search information about the travel, $24 \%$ do it often, $16 \%$ sometimes, and $12 \%$ exclusively. Only $2 \%$ do not use the Internet for that purpose.

As regards booking airline tickets, $50 \%$ of respondents do not use the Internet for that purpose, $30 \%$ do it sometimes, $10 \%$ often, while $10 \%$ of respondents do it regularly or exclusively. The situation is similar for the use of the Internet in booking accommodation. Namely, 50\% do not use the Internet and $40 \%$ use it sometimes, $10 \%$ of respondents use the Internet often, regularly or exclusively.

A large group of respondents (62\%) never use the Internet for booking package tours, $28 \%$ use it sometimes, while only $10 \%$ of respondents use the Internet often or regularly. None of respondents marked answer "exclusively".

Research results also show that respondents think that booking of travel services/package tours over the Internet is cheaper (76\%) while $34 \%$ respondents consider it expensive.

There is a noticeable difference between using the Internet for booking travel and tourism services in the country and those services that are booked over the Internet abroad. The Internet is more used for booking services in the country (50\%) while $22 \%$ respondents use the Internet to book services abroad. On the other hand, $76 \%$ of respondents prefer booking services abroad via travel agency/tour operator, whereas $46 \%$ use travel agency/ tour operator services when travelling within the country.

Face to Face is the most preferred type of interaction in communication with the travel agency/tour operator $-94 \%$ of respondents.

As far as consulting with other tourists over the Internet about tourism and travel services, $36 \%$ of respondents never consult over the Internet, $40 \%$ do it sometimes, $20 \%$ often and only $6 \%$ of respondents do it on a regular basis. 


\begin{tabular}{|c|c|c|c|}
\hline & & Count & Column N \% \\
\hline \multirow[t]{5}{*}{$\begin{array}{l}\text { How many times a year do you go on a trip that lasts } \\
\text { more than } 2 \text { (two) days }\end{array}$} & $1-2$ times & 20 & $40 \%$ \\
\hline & 3-4 times & 12 & $24 \%$ \\
\hline & 5-6 times & 12 & $24 \%$ \\
\hline & More than 6 times & 4 & $8 \%$ \\
\hline & Do not travel & 2 & $4 \%$ \\
\hline \multirow[t]{3}{*}{ How do you usually travel? } & With tour operator/travel agency & 27 & $54 \%$ \\
\hline & Individually & 22 & $44 \%$ \\
\hline & No answer & 1 & $2 \%$ \\
\hline \multirow[t]{4}{*}{ When choosing a travel agency/tour operator } & $\begin{array}{l}\text { I choose those whose services I have already used } \\
\text { before }\end{array}$ & 22 & $44 \%$ \\
\hline & Visit the nearest one & 3 & $6 \%$ \\
\hline & I am often changing tour operators/travel agencies & 14 & $28 \%$ \\
\hline & Do not use a travel agency/tour operator services & 11 & $22 \%$ \\
\hline \multirow[t]{5}{*}{$\begin{array}{l}\text { Do you use the Internet for searching information } \\
\text { about the travel? }\end{array}$} & Never & 1 & $2 \%$ \\
\hline & Sometimes & 8 & $16 \%$ \\
\hline & Often & 12 & $24 \%$ \\
\hline & Regularly & 23 & $46 \%$ \\
\hline & Exclusively & 6 & $12 \%$ \\
\hline \multirow[t]{5}{*}{ Do you use the Internet for booking airline tickets } & Never & 25 & $50 \%$ \\
\hline & Sometimes & 15 & $30 \%$ \\
\hline & Often & 5 & $10 \%$ \\
\hline & Regularly & 2 & $4 \%$ \\
\hline & Exclusively & 3 & $6 \%$ \\
\hline \multirow[t]{5}{*}{ Do you use the Internet for booking accommodation } & Never & 25 & $50 \%$ \\
\hline & Sometimes & 20 & $40 \%$ \\
\hline & Often & 2 & $4 \%$ \\
\hline & Regularly & 2 & $4 \%$ \\
\hline & Exclusively & 1 & $2 \%$ \\
\hline \multirow[t]{5}{*}{ Do you use the Internet for booking package tours } & Never & 31 & $62 \%$ \\
\hline & Sometimes & 14 & $28 \%$ \\
\hline & Often & 3 & $6 \%$ \\
\hline & Regularly & 2 & $4 \%$ \\
\hline & Exclusively & 0 & $0 \%$ \\
\hline \multirow[t]{2}{*}{$\begin{array}{l}\text { Booking travel services/package tours over the Inter- } \\
\text { net in your opinion is: }\end{array}$} & Expensive & 12 & $24 \%$ \\
\hline & Cheaper & 38 & $76 \%$ \\
\hline \multirow[t]{3}{*}{ Your holiday travel abroad is mainly booked: } & via the Internet & 11 & $22 \%$ \\
\hline & via travel agency/tour operator & 38 & $76 \%$ \\
\hline & No answer & 1 & $2 \%$ \\
\hline \multirow[t]{3}{*}{ Your holiday travel within Serbia is mainly booked: } & via the Internet & 25 & $50 \%$ \\
\hline & via travel agency/tour operator & 23 & $46 \%$ \\
\hline & No answer & 2 & $4 \%$ \\
\hline \multirow[t]{5}{*}{$\begin{array}{l}\text { What kind of interaction do you prefer in communi- } \\
\text { cation with travel agencies/tour operators: }\end{array}$} & Face to face & 47 & $94 \%$ \\
\hline & By telephone & 1 & $2 \%$ \\
\hline & E-mail & 1 & $2 \%$ \\
\hline & The Internet chat & 0 & $0 \%$ \\
\hline & No answer & 1 & $2 \%$ \\
\hline \multirow[t]{5}{*}{$\begin{array}{l}\text { How often do you consult about tourism and travel } \\
\text { services with other tourists over the Internet: }\end{array}$} & Never & 16 & $32 \%$ \\
\hline & Sometimes & 20 & $40 \%$ \\
\hline & Often & 10 & $20 \%$ \\
\hline & Regularly & 3 & $6 \%$ \\
\hline & No answer & 1 & $2 \%$ \\
\hline
\end{tabular}

Table 1. Respondents' answers 


\section{EVALUATING BOOKING OVER THE INTERNET IN SERBIA}

Respondents have evaluated booking over the Internet in Serbia using a 5 - point Likert scale: 1 - low grade; 2 - poor grade; 3 - average grade; 4 - good grade; 5 - excellent grade. Results are shown in Table 2.

\begin{tabular}{ccccccccc}
\hline & $\mathrm{N}$ & Min. & Max. & \multicolumn{2}{c}{ Mean } & \begin{tabular}{c} 
Std. \\
\cline { 5 - 6 }
\end{tabular} \\
& & & Statistic & $\begin{array}{c}\text { Std. } \\
\text { Error }\end{array}$ & $\begin{array}{c}\text { via- } \\
\text { tion }\end{array}$ \\
\hline $\begin{array}{c}\text { Benefits of booking } \\
\begin{array}{c}\text { T\&T services over the } \\
\text { Internet in Serbia }\end{array}\end{array}$ & 46 & 1 & 5 & 3.217 & 0.126 & 0.892 \\
\hline
\end{tabular}

Table 2. Booking over the Internet in Serbia

Respondents also evaluated sense of security while booking over the Internet according to Likert scale: 1 - extremely unsafe; 2 - unsafe; 3 - moderately safe; 4 - safe; 5 - extremely safe. Results are shown in table 3 .

\begin{tabular}{cccccccc}
\hline & $\mathrm{N}$ & Min. & Max. & & \multicolumn{2}{c}{ Mean } & Std. \\
\cline { 5 - 7 } & Statistic & $\begin{array}{c}\text { Std. } \\
\text { Error }\end{array}$ & $\begin{array}{c}\text { Devia- } \\
\text { tion }\end{array}$ \\
\hline $\begin{array}{c}\text { Sense of security when } \\
\text { booking T\&T ser- } \\
\text { vices over the Internet } \\
\text { in Serbia }\end{array}$ & 46 & 1 & 5 & 2.782 & 0.152 & 1.073 \\
\hline
\end{tabular}

Table 3. Sense of security while booking

Respondents have evaluated that the benefits of booking travel and tourism services over the Internet in Serbia are average $(M=3.217 ; S D=0.892)$, also implying that security of booking is in between unsafe and moderately safe $(\mathrm{M}=2.782 ; \mathrm{SD}=1.073)$.

\section{BOOKING TOURISM AND TRAVEL SERVICES OVER TRAVEL AGENCY/TOUR OPERATOR}

Respondents have evaluated booking over travel agency/ tour operator in Serbia. The main purpose of this evaluation was to find out how much the expertise and professionalism of employees in travel agencies/tour operators affect tourists to book tourism and travel services at the offices of the travel agency/ tour operator instead of using the Internet. For the purpose of evaluation, a five-point Likert scale is used: 1 - extremely does not affect; 2 - it does not affect; 3 - moderately affects 4 - affects a lot, 5 - Highly affected. Research results are shown in Table 4.

\begin{tabular}{|c|c|c|c|c|c|c|}
\hline & \multirow[b]{2}{*}{$\mathrm{N}$} & \multirow[b]{2}{*}{ Min. } & \multirow[b]{2}{*}{ Max. } & \multicolumn{2}{|c|}{ Mean } & \multirow{2}{*}{$\begin{array}{c}\text { Std. } \\
\text { Devia- } \\
\text { tion }\end{array}$} \\
\hline & & & & Statistic & $\begin{array}{l}\text { Std. } \\
\text { Error }\end{array}$ & \\
\hline $\begin{array}{l}\text { How much do the } \\
\text { expertise and profes- } \\
\text { sionalism of employees } \\
\text { in travel agencies/tour } \\
\text { operators affect your } \\
\text { choice to book travel } \\
\text { and tourism services } \\
\text { at the offices of travel } \\
\text { agency/tour operator } \\
\text { instead of using the } \\
\text { Internet? }\end{array}$ & 47 & 1 & 5 & 3.936 & 0.133 & 0.942 \\
\hline
\end{tabular}

Table 4. The influence of expertise and professionalism on booking
Respondents also emphasized the importance of interaction with travel agents during the process of booking services. They evaluated the importance of choosing between two extreme claims ( 1 - it is essential; 7 - does not matter), with the variations in opinion being on the scale from 1 to 7 . Research results are shown in Figure 3.

\section{Importance of interaction with travel agent}

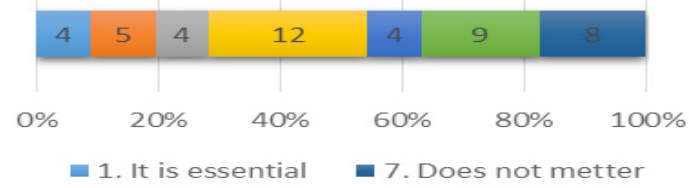

Figure 3. Importance of interaction

Based on the results, expertise and professionalism of employees in travel agencies/tour operators considerably affect tourists when booking tourism and travel services at the offices of the travel agency/tour operator instead of using the Internet $(\mathrm{M}=3.936 ; \mathrm{SD}=0.942)$. Out of 46 respondents, who answered the question, 28\% think that importance of interaction with travel agents is more essential while those who think that it does not matter account for $45 \%$. A large group of respondents (26\%) did not clearly state their opinion on how important the interaction with travel agents is in the process of booking services.

\section{SURVIVAL OF TRAVEL AGENCIES AND TOUR OPERATORS IN THE FUTURE}

Respondents were asked whether the classic travel agencies and traditional tour operators will survive in accordance with the changes brought about by the Internet. As seen in Fig. 4 and Fig. 5, results indicate that $52 \%$ of respondents state that classic travel agencies will not disappear from the market under the influence of the Internet in tourism and travel distribution, while $28 \%$ did not answer the question. On the other hand, $20 \%$ of respondents do not agree with that. In the case of tour operators, the situation is almost the same. The same percentage of $52 \%$ respondents agree that traditional approach in tour operators distribution will not be affected mainly by changes brought by the Internet, while only $12 \%$ think opposite.

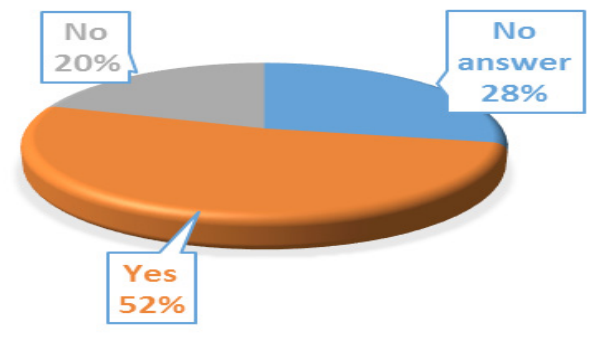

Figure 4. Market survival of classic travel agencies 


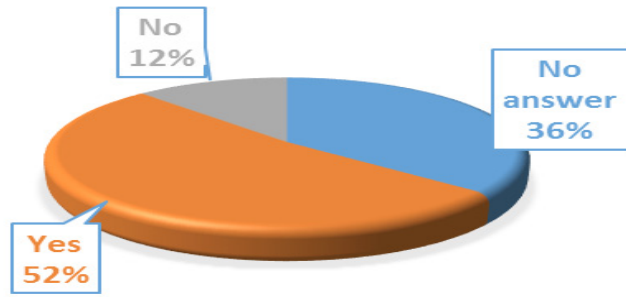

Figure 5. Market survival of traditional tour operators

\section{IDENTIFIED PROS AND CONS}

This research identifies several features affecting the Internet-based and traditional travel agencies and tour operators. Based on the results, the study confirms that the use of the Internet in Serbia, as a tool for booking services and overall distribution, is not yet developed in line with the global trends. People tend to place their trust in traditional agencies more than they do in booking over the Internet. Most of the respondents imply that they use the Internet sometimes or never for booking tourism and travel services online even though the booking over the Internet is cheaper. A great number of respondents use travel agency/tour operator services for travelling, while the use of the Internet is more present in domestic tourism. Also, tourists do not prefer much the Internet booking when traveling abroad and to remote destinations. Moreover, a large percentage of those who choose tour operators prefer the services they used before. This implies that experience and loyalty play a significant role in booking tourism and travel services in Serbia. Based on the research results, face to face communication with travel agencies/tour operators leads to the conclusion that Serbian market is still not "online booking intensive". On the other hand, trust and security of such tourists when booking face to face with the agent is evident and the feeling that someone is "responsible" for their trip or package tour realisation. Expertise and professionalism of employees in travel agencies/tour operators greatly affect tourist choice and decision-making even more than consulting with tourists over the Internet. The Internet in Serbia is mostly used for searching the information. The respondents who use the Internet do it more often to buy airline tickets rather than to book package tours and accommodation.

\section{SUMMARY}

A number of studies, including this one have certain limitations, and thus needs to be taken into consideration. The main limitation is associated with the nature of the sample and data collection. The largest part of the sample includes age groups of young people between 18-25 years old, while only 6 respondents are over 25 . The results cannot be generalized to all young people since the respondents were the students predominately of the same age. Future research should be extended to a larger groups of young people and include measurement of specific indicators of experience and motivation. On the other hand, obtaining more precise information on travel agencies and tour operators benefits is also recommended. This study does not include the views of tour operators and travel agencies which could define more precisely constraints about traditional and online distribution.
The results point out the necessity for greater information intensity of tourism market in Serbia. Travel agencies and tour operators in Serbia mainly use the Internet for providing information. This market is not yet enough mature and there is not much confidence in booking and paying via the Internet. On the other hand, the results indicate that the tendency of travel agencies and tour operators, oriented towards traditional distribution of services, will not disappear from the market. The tourist confidence and sense of security pose a determining factor in selecting the form of booking. Based on the research results, we suggest that travel agencies and tour operators should place greater emphasis on the use of the Internet in their business, but at the same time, they should nourish traditional advantages that tourists find so important in the distribution process. This indicates that travel agencies and tour operators should make their business more e-commerce oriented. This is mostly in alignment with traditional travel agencies' reorientation to electronic commerce-able intermediaries (EC able). These subjects are able to retain the traditional approaches to business and connect with EC-only travel agencies using them as technology providers. This is called the "Reintermediation phase" (Cheung \& Lam, 2009).

\section{REFERENCES}

Buhalis, D., \& Licata, M.C. (2002). The Future eTourism intermediaries. Tourism Management, 23, 207-220. DOI: 10.1016/ S0261-5177(01)00085-1

Buhalis, D., \& Laws E. (2001). Tourism Distribution Channels: Patterns, Practices and Challenges. London: Thompson.

Cheung, R., \& Lam, P. (2009). How Travel Agency Survive in eBusiness World? Lam Communications of the IBIMA. 10, 85-92. DOI: $10.1177 / 1096348012442544$

Chiappa, G. (2013). The Internet versus travel agencies: The perception of different groups of Italian online buyers. Journal of Vacation Marketing. 19(1), 55-66. DOI: 10.1177/1356766712466613

European Commission, Flash Eurobarometar 392. (2014). Preferences of Europeans towards Tourism. Retrieved, February 1, 2015 from http://ec.europa.eu/public_opinion/flash/ fl_392_en.pdf

Holloway, J.C. (2004). Marketing for Tourism. England: Pearson Education.

Lang, T. (2000). The Effect of the Internet on Travel Consumers Purchasing Behavior and Implications for Travel Agencies. Journal of Vacation Marketing. 6, 368-385. DOI: $10.1177 / 135676670000600407$

Oxford Economics \& Amadeus. (2014). Shaping the Future of Travel - Macro trends driving industry growth over the next decade. Retrieved, February 1, 2015 from http://www.amadeus.com/documents/Thought-leadership-reports/Amadeus-Shaping-the-Future-of-Travel-MacroTrends-Report.pdf

PhoCusWright Inc. (2011). Global Online Travel Overview. Retrieved, February 1, 2015 from: http://sete.gr/_fileuploads/entries/Online\%20library/GR/110419_Global\%20Online\%20 Travel\%20Overview\%20Second\%20Edition.pdf

Poon, A. (2001). The future of travel agents. Travel \& Tourism Analyst, 3, 57-80.

Poon, A. (1993). Tourism, Technology and Competitive Strategies. Oxford: CAB International.

Schitko, D. \& Losekoot, E. (2012). An Investigation of the Attitudes of Travel and Tourism Intermediaries to Mature Travelers. Journal of Tourism, 8(1), 62-78 
Simoff, S., Bogdanovych, A., Berger, H. \& Sierra, C. (2006). Travel agents vs. online booking: Tackling the shortcomings of nowadays online tourism portals. In 13th International Conference on Information Technologies in Tourism - ENTER 2006, (pp. 418-428) Lausanne, Switzerland

Spasić, V., Njeguš, A., \& Pavlović, D. (2014). Modern information technologies application in destination management companies, SINTEZA 2014; Impact of the Internet on Business activities in Serbia and Worldwide; E-Business in tourism and hospitality industry, (pp. 772-776). DOI: 10.15308/SInteZa-2014-772-776
Xianga, Z., Magninia, V. P. \& Fesenmaierb, D. (2015). Information technology and consumer behavior in travel and tourism: Insights from travel planning using the Internet. Journal of Retailing and Consumer Services, 22, 244-249. DOI: 10.1016/j.jretconser.2014.08.005

Zikmund, W., Babin, B., Carr, J., \& Griffin, M. (2010). Business Research Methods. Mason, OH: Thomson. 